\title{
EDITORIAL
}

\section{MEPS: a unique journal celebrates its 10 th year of existence and the appearance of its 50th volume}

\author{
O. Kinne \\ Ecology Institute, Nordbünte 23, D-2124 Oldendorf/Luhe, Federal Republic of Germany
}

Marine Ecology Progress Series (MEPS) was founded in 1979. Now, in 1988, the journal celebrates its 10 th year of publishing and the appearance of its 50 th volume. The short history of MEPS has been characterized by close international cooperation among the members of its large Editorial. Board residing in all major culture nations; by a high-quality and fast peer-review process resulting in the publication of critically improved and carefully selected articles; by rapid publication of accepted manuscripts; and by an explosive expansion of the journal's publication capacity.

In fact, MEPS is a unique journal in several ways: (1) Seven years after its foundation the journal achieved recognition as the world's Number 1 in marine ecological journal publication. (2) Within the same period of time, publication rate rose from $1 / 2$ volume per year to 8 volumes per year. (3) To my knowledge, MEPS is the only commercially operating scientific journal that spends a significant part of its income on promoting research. The journal sponsors the Ecology Institute (ECI), an international nonprofit organization of leading research ecologists, devoted to honoring and supporting excellence in ecological research, furthering the exchange between marine, terrestrial and limnetic ecologists, and to narrowing the gap between ecological science and its application for the benefit of nature and society. ECI's activities have been outlined in Volume 34 of MEPS (Kinne 1986). They include the awarding of prizes and the publication, at cost price, of books authored by Prize Winners in the series 'Excellence in Ecology'.

Another unique feature of the journal is the MEPS SPECIAL. This year we have, for the first time, published a special volume (Volume 46), containing a coherent set of papers, representing well-integrated ad hoc efforts of experts and addressing a specific and significant issue of current ecological research: 'Biological effects of pollutants' (Bayne et al. 1988). The 1988 MEPS SPECIAL results from a practical workshop held in August 1986 in Oslo, Norway, and documents our present capacities for assessing the biological consequences of pollution in the sea. The Volume has drawn considerable attention and, thus far, exclusively positive comments. MEPS SPECIALS are also available in hard-cover form for those scientists whose library does not subscribe to the journal but who wish to have the volume permanently on their desk. "

That MEPS is the Number 1 was established in several questionaires; numerous letters from top performers in the field addressed to MEPS's editor; 2 lectures by Fuseler-McDowell delivered at the annual meetings of the International Association of Marine Science Libraries and Information Centers, held 1987 in Halifax, Nova Scotia, Canada and 1988 in Miami, Florida, USA (Fuseler-McDowell in press a, b); and an article by Garfield (1987) published in 'Current Contents'. Fuseler-McDowell and Garfield considered citation data, impact factors and immediacy indexes. Referring to oceanography at large, Garfield lists MEPS as one of the 'five outstandingly significant journals' (p. 11). Fuseler-McDowell determined the 4 most influential journals - the central core - for the fields of oceanography and marine biology (Table 1). From her analyses MEPS emerges as the only central core journal featuring in both groups - and MEPS is the youngest of all the journals selected.

MEPS' 10 th year of existence and the publication of its 50 th volume give the Editor a welcome opportunity to thank sincerely and cordially all members of our large team.

Success has many fathers. However, to me it is clear that our Editorial Advisors and Referees - all carefully selected and internationally acknowledged experts played a major role. Throughout MEPS's 10 years of existence, the Editorial Advisors actively participated in developing and sustaining the journal's quality standard. The Advisors critically, constructively and

\footnotetext{
- Please address your order to Inter-Research, PO Box 1120 , D-2124 Amelinghausen, F. R. Germany
} 
Table 1. Alphabetical lists of the 4 most influential journals in the fields of oceanography and marine biology. Based on documentations by Fuseler-McDowell (in press $a, b$ ) who kindly made the manuscripts of her papers available

\begin{tabular}{|c|c|c|c|}
\hline \multicolumn{2}{|c|}{ Oceanography } & \multicolumn{2}{|c|}{ Marine biology } \\
\hline Journal & First year of publication & Journal & First year of publication \\
\hline Deep-Sea Research & 1953 & $\begin{array}{l}\text { Canadian Journal of } \\
\text { Fisheries and Aquatic Sciences }\end{array}$ & 1934 \\
\hline $\begin{array}{l}\text { Journal of Physical } \\
\text { Oceanography }\end{array}$ & 1971 & $\begin{array}{l}\text { Journal of Experimental } \\
\text { Marine Biology and Ecology }\end{array}$ & 1967 \\
\hline $\begin{array}{l}\text { Limnology and } \\
\text { Oceanography }\end{array}$ & 1956 & Marine Biology & 1967 \\
\hline $\begin{array}{l}\text { Marine Ecology } \\
\text { Progress Series }\end{array}$ & 1979 & $\begin{array}{l}\text { Marine Ecology } \\
\text { Progress Series }\end{array}$ & 1979 \\
\hline
\end{tabular}

promptly evaluated the scientific merits of manuscripts submitted; several of them selected high-quality manuscripts, handled these editorially and presented the final product for publication; and they suggested topics and authors for reviews. The efforts of Editorial Advisors (about 110), the work of numerous anonymous Referees, the intensive and close cooperation between Editor and Advisors/Referees, and the enthusiasm of all of us - this I consider to be the heart of MEPS and the basis of its unique success. The work with MEPS has considerably enriched my own insight into the scientific process and led to a keynote address presented at the 1987 Conference of the International Federation of Scientific Editors's Association, held in Hamburg (F. R. Germany), and a subsequent publication (Kinne 1988).

Here in Oldendorf/Luhe - the 'headquarters' of MEPS - it was primarily Helga Witt, Helga Kinne, Marita Bruns, and - last but certainly not least - MEPS' Assistant Editor John Austin who saw to it that everything proceeded effectively, smoothly and quickly. On the side of the publisher, Inter-Research, and the printer, Westholsteinische Verlagsdruckerei Boyens \& Co., a pronounced sense of quality provided a solid basis for our work. Herr U. Boyens and his associate
Herr $H$. Bode have assisted in many ways in the foundation and development of MEPS. I am grateful for all this support and for the warm and positive response that MEPS has received from the international scientific community right from the beginning. My coworkers here in Oldendorf/Luhe and I shall continue to do our very best to maintain and develop the journal's high standards, and to keep MEPS attractive to both authors and readers.

\section{LITERATURE CITED}

Bayne, B. L., Clarke, K. R., Gray, J. S. (eds.) (1988). Biological effects of pollutants. Mar. Ecol. Prog. Ser. 46: 1-278

Fuseler-McDowell, E. (in press a). Documenting the literature of oceanography. Proceedings of the International Association of Marine Science Libraries and Information Centers

Fuseler-McDowell, E. (in press b). Documenting the literature of marine biology. Proceedings of the International Association of Marine Science Libraries and Information Centers

Garfield, E. (1987). Current comments. Journal citation studies 47. Which oceanography journals make the biggest waves? Current Contents 48: 3-11

Kinne, O. (1986). The Ecology Institute - its activities, prizes, funding, and staff. Mar. Ecol. Prog. Ser. 34: 1-5

Kinne, O. (1988). The scientific process - its links, functions and problems. Naturwissenschaften 75: 275-279 